\title{
CT-derived muscle remodelling after bronchoscopic lung volume reduction in advanced emphysema
}

Citation for published version (APA):

Sanders, K. J. C., Klooster, K., Vanfleteren, L. E. G. W., Slebos, D-J., \& Schols, A. M. W. J. (2019). CTderived muscle remodelling after bronchoscopic lung volume reduction in advanced emphysema. Thorax, 74(2), 206-207. https://doi.org/10.1136/thoraxjnl-2018-211931

Document status and date:

Published: 01/02/2019

DOI:

10.1136/thoraxjnl-2018-211931

Document Version:

Publisher's PDF, also known as Version of record

Document license:

Taverne

Please check the document version of this publication:

- A submitted manuscript is the version of the article upon submission and before peer-review. There can be important differences between the submitted version and the official published version of record.

People interested in the research are advised to contact the author for the final version of the publication, or visit the DOI to the publisher's website.

- The final author version and the galley proof are versions of the publication after peer review.

- The final published version features the final layout of the paper including the volume, issue and page numbers.

Link to publication

\footnotetext{
General rights rights.

- You may freely distribute the URL identifying the publication in the public portal. please follow below link for the End User Agreement:

www.umlib.nl/taverne-license

Take down policy

If you believe that this document breaches copyright please contact us at:

repository@maastrichtuniversity.nl

providing details and we will investigate your claim.
}

Copyright and moral rights for the publications made accessible in the public portal are retained by the authors and/or other copyright owners and it is a condition of accessing publications that users recognise and abide by the legal requirements associated with these

- Users may download and print one copy of any publication from the public portal for the purpose of private study or research.

- You may not further distribute the material or use it for any profit-making activity or commercial gain

If the publication is distributed under the terms of Article $25 \mathrm{fa}$ of the Dutch Copyright Act, indicated by the "Taverne" license above, 


\title{
CT-derived muscle remodelling after bronchoscopic lung volume reduction in advanced emphysema
}

\author{
Karin J C Sanders, ${ }^{1}$ Karin Klooster, ${ }^{2}$ Lowie E G W Vanfleteren, ${ }^{3}$ Dirk-Jan Slebos, ${ }^{2}$ \\ Annemie M W J Schols ${ }^{1}$
}

- Additional material is

published online only. To view please visit the journal online (http://dx.doi.org/10.1136/ thoraxjn-2018-211931).

${ }^{1}$ Department of Respiratory Medicine, NUTRIM School of Nutrition and Translational Research in Metabolism, Maastricht University Medical Centre, Maastricht, The Netherlands ${ }^{2}$ Department of Pulmonary Diseases, University of Groningen, University Medical Centre Groningen, Groningen, The Netherlands ${ }^{3}$ COPD Centre Sahlgrenska University, Gothenburg, Sweden

\section{Correspondence to}

Professor Annemie M W J Schols, Department of Respiratory Medicine, NUTRIM School of Nutrition and Translational Research in Metabolism, Maastricht University Medical Centre, Maastricht 200 MD, The Netherlands; a.schols@maastrichtuniversity.nl

Received 12 April 2018 Revised 26 July 2018 Accepted 30 July 2018 Published Online First 12 August 2018

\section{Check for updates}

(C) Author(s) (or their employer(s)) 2019. No commercial re-use. See rights and permissions. Published by BMJ.

To cite: Sanders KJC, Klooster K, Vanfleteren LEGW, et al. Thorax

2019:74:206-207

\section{ABSTRACT}

Muscle wasting frequently occurs in severe emphysema. Improving respiratory mechanics by bronchoscopic lung volume reduction using endobronchial valves (EBV) might prevent further loss or even increase in muscle mass. CT-derived skeletal muscle mass gain was observed in 39/49 patients 6 months after EBV. Multiple linear regression showed that gain in muscle $(\beta=2.4 ; 95 \% \mathrm{Cl}$

0.2 to $4.6 ; p=0.036)$ and intramuscular fat $(\beta=3.1 ; 95 \%$ $\mathrm{Cl} 0.2$ to $5.9 ; \mathrm{p}=0.035)$ is associated with improved 6 min walk distance independent of the change in residual volume. Skeletal muscle remodelling associates with improved exercise capacity after EBV, independent of hyperinflation reduction.

Trial registration number Clinical trial registered with the Dutch trial register www.trialregister.nl (NTR2876), Results.

\section{INTRODUCTION}

The emphysematous COPD phenotype is prone to develop cachexia (ie, unintended weight loss and muscle wasting), ${ }^{1}$ adversely affecting morbidity and mortality. ${ }^{12}$ Patients with severe emphysema have limited treatment options and the efficacy of pulmonary rehabilitation on muscle function and exercise performance is hampered by impaired respiratory mechanics. Recently, lung volume reduction has regained new interest by the arrival of non-invasive bronchoscopic lung volume reduction. Bronchoscopic placement of endobronchial valves (EBV) has been shown to significantly improve symptoms, exercise capacity and quality of life. ${ }^{3}$

The impairment of exercise tolerance in severe emphysema results from ventilatory limitation, deconditioning and loss of muscle mass and oxidative metabolism. ${ }^{45}$ While improved lung function after EBV treatment was accompanied by exercise capacity and physical activity, ${ }^{36}$ the effect of EBV on muscle loss is unknown.

We hypothesise that hyperinflation reduction results in restoration of energy balance which increases body weight and maintains or increases muscle mass contributing to improved exercise capacity.

\section{METHODS}

A post hoc analysis of a randomised controlled crossover trial investigating EBV treatment conducted at the University Medical Centre Groningen in the Netherlands (STELVIO trial NTR2876) was performed. The full and detailed methodology of this study has been published previously. ${ }^{3}$ CT images were obtained at baseline and 6 months follow-up after EBV treatment. Skeletal muscle and adipose tissue cross-sectional area were analysed on single-slice CT scan at the first lumbar level. These structures were quantified on the basis of pre-established thresholds of Hounsfield units. The mean Hounsfield units of the muscle cross-sectional area were assessed as a proposed measure of muscle quality, ${ }^{7}$ whereby low values reflect increased fat deposits. Further details of the methods and statistical analyses are in the online Supplementary file 1.

\section{RESULTS}

CT scans from 49 enrolled patients were eligible (online Supplementary file 2). Baseline characteristics are displayed in the online Supplementary file 1.

Changes in skeletal muscle and adipose tissue are depicted in table 1. After EBV treatment, body weight, skeletal muscle, intramuscular fat and subcutaneous fat cross-sectional area significantly increased, while mean skeletal muscle Hounsfield units remained unchanged. Despite a similar improvement in lung function parameters, muscle mass was maintained or increased in the majority of patients (80\%), whereas 20\% experienced muscle loss.

Patients significantly improved in residual volume and their 6MWD after EBV treatment as previously reported for the total cohort. ${ }^{3}$ By use of multiple linear regression analysis, adjusted for gender and baseline $6 \mathrm{MWD}$, skeletal muscle mass $(\beta=2.4$; $95 \%$ CI 0.2 to $4.6 ; \mathrm{p}=0.036)$ and intramuscular fat $(\beta=3.1 ; 95 \%$ CI 0.2 to $5.9 ; p=0.035)$ but not the change in residual volume, associated with $6 \mathrm{MWD}$ improvement (table 2).

\section{DISCUSSION}

This is to our knowledge the first study to present changes in skeletal muscle and adipose tissue mass and distribution after EBV in patients with advanced emphysema derived from chest CT analysis. Skeletal muscle remodelling associated with increased exercise capacity, independent of the degree of reduced hyperinflation.

Mineo et $\mathrm{l}^{8}$ previously investigated body composition in patients with emphysema by dual-energy X-ray absorptiometry (DEXA), prior to and 1, 3 and 5 year following lung volume reduction surgery. A sustained increase of whole-body fat mass and fat-free mass was reported in patients treated with lung volume reduction surgery, while a decline in fat and fat-free mass was observed after 3 and 5 years in patients who received usual care. DEXA analyses, however, do not allow direct quantification of muscle mass or intramuscular changes. 


\begin{tabular}{|c|c|c|}
\hline & Absolute change & $P$ values \\
\hline Weight, $95 \% \mathrm{Cl}(\mathrm{kg})$ & $1.3(0.5$ to 2.1$)$ & 0.001 \\
\hline $\begin{array}{l}\text { Skeletal muscle cross-sectional area, } \\
\text { median (range) }\left(\mathrm{cm}^{2}\right)\end{array}$ & $2.4(-14.4$ to 16.6$)$ & 0.002 \\
\hline $\begin{array}{l}\text { Hounsfield unit skeletal muscle, } \\
95 \% \mathrm{Cl}\end{array}$ & $-0.1(-1.3$ to 0.6$)$ & 0.882 \\
\hline $\begin{array}{l}\text { Intramuscular fat cross-sectional area, } \\
\text { median (range) }\left(\mathrm{cm}^{2}\right)\end{array}$ & $1.3(-7.0$ to 23.8$)$ & 0.017 \\
\hline $\begin{array}{l}\text { Subcutaneous fat cross-sectional area, } \\
\text { median (range) }\left(\mathrm{cm}^{2}\right)\end{array}$ & 5.3 (-68.8 to 38.3$)$ & 0.014 \\
\hline Residual volume, 95\% Cl (\%) & $-17.0(-20.5$ to -13.5$)$ & $<0.001$ \\
\hline $6 \mathrm{MWD}, 95 \% \mathrm{Cl}(\mathrm{m})$ & 72.4 (57.7 to 91.2$)$ & $<0.001$ \\
\hline
\end{tabular}

6MWD, 6 min walk distance.

A remarkable observation in this study was the observed increase in intramuscular fat associated with improved exercise performance independent of muscle cross-sectional area. The observed muscle remodelling may enhance exercise performance by improving muscle strength but also by alleviating fatigue. In line with the athlete's paradox, the observed increase in intramuscular adipose tissue could reflect improved muscle mitochondrial metabolism and insulin sensitivity via an effect of peroxisome proliferator-activated receptor gamma coactivator-1 on intramuscular lipid programming. ${ }^{9}$ Supportive for this hypothesis are two studies by Mineo et al showing that resting metabolic rate after lung volume reduction surgery was associated with a conversion from prevalent lipid to carbohydrate metabolism ${ }^{8}$ and demonstrating a reduction in insulin resistance, ${ }^{10}$ but obviously this requires further in-depth investigation.

Although the strength of our study comes from the well-defined randomised patient cohort, there are some limitations. Gender distribution in the study population was unequal with a predominance of females. We adjusted for gender in statistical analyses, but the sample size did not allow investigating putative gender differences in the response. We do not expect profound differences as the previous studies by Mineo et $a l^{810}$ were performed in males. Furthermore, while the standard site to measure muscle tissue as proxy for whole body muscle mass is the third lumbar vertebra; this is typically outside the field of view of clinically acquired

Table 2 Multivariate analysis for predictors of change in 6MWD, corrected for gender $(n=45)$

\begin{tabular}{lrlc}
\hline & B & $95 \% \mathrm{Cl}$ & P values \\
\hline$\Delta$ Skeletal muscle cross-sectional area, $\mathrm{cm}^{2}$ & 2.4 & 0.16 to 4.63 & 0.036 \\
$\Delta$ Intramuscular fat cross-sectional area, $\mathrm{cm}^{2}$ & 3.1 & 0.23 to 5.94 & 0.035 \\
6MWD baseline & -0.3 & -0.49 to -0.17 & $<0.001$ \\
\hline Residual volume, \% & -0.7 & -1.93 to 0.48 & 0.232 \\
\hline
\end{tabular}

6MWD, 6 min walk distance.
CT imaging in patients with COPD. Therefore, in this study, we analysed CT scans at the level of the first lumbar vertebra. This hampered analysis of visceral fat mass, because CT scans at this level frequently include the lower lung lobes. Furthermore, a minimal clinically important difference is not yet been determined. We furthermore recognise that CT slice derived intramuscular fat cannot distinguish between intramyocellular and extramyocellular lipids. This requires additional biopsy-derived muscle tissue analysis. We did not observe changes in the mean Hounsfield units of the muscle cross-sectional area as proxy for muscle fat deposits, which might be due to the sample size.

In conclusion, bronchoscopic lung volume reduction treatment using one-way endobronchial valves induces muscle remodelling in patients with severe emphysema which associates with improvements in exercise performance.

Contributors KJCS, KK, D-JS and AMWJS contributed to the conception and design of the article. KJCS and AMWJS contributed to the analysis of data. All authors contributed to the interpretation of data, drafting of the manuscript, critically revised the article and gave final approval of this version to be submitted.

Funding Supported by MUMC2020 grant. The sponsor was not involved in the study design, data collection and analysis, writing of the report and in the decision for publication.

Competing interests KJCS has nothing to disclose. KK reports non-financial support from ZonMW, The Hague, NL (government granting agency), during the conduct of the study; grants, personal fees, non-financial support and other from PneumRx/BTG, CA, USA, grants, personal fees, non-financial support and other from PulmonX, CA, USA, outside the submitted work. LEGWV has nothing to disclose. D-JS reports grants, personal fees, non-financial support and other from PulmonX Inc., CA, USA, outside the submitted work. AMWJS has nothing to disclose.

\section{Patient consent Obtained.}

Provenance and peer review Not commissioned; externally peer reviewed.

\section{REFERENCES}

1 Vanfleteren LE, Spruit MA, Groenen M, et al. Clusters of comorbidities based on validated objective measurements and systemic inflammation in patients with chronic obstructive pulmonary disease. Am J Respir Crit Care Med 2013;187:728-35.

2 Burgel PR, Paillasseur JL, Peene B, et al. Two distinct chronic obstructive pulmonary disease (COPD) phenotypes are associated with high risk of mortality. PLoS One 2012;7:e51048.

3 Klooster K, ten Hacken NH, Hartman JE, et al. Endobronchial valves for emphysema without interlobar collateral ventilation. N Engl J Med 2015;373:2325-35.

4 Remels AH, Schrauwen P, Broekhuizen R, et al. Peroxisome proliferatoractivated receptor expression is reduced in skeletal muscle in COPD. Eur Respir J 2007;30:245-52

5 Pitta F, Troosters T, Probst VS, et al. Physical activity and hospitalization for exacerbation of COPD. Chest 2006;129:536-44.

6 Hartman JE, Klooster K, Slebos DJ, et al. Improvement of physical activity after endobronchial valve treatment in emphysema patients. Respir Med 2016:117:116-21.

7 Goodpaster BH, Kelley DE, Thaete FL, et al. Skeletal muscle attenuation determined by computed tomography is associated with skeletal muscle lipid content. J Appl Physiol 2000;89:104-10. 1985

8 Mineo D, Ambrogi V, Lauriola V, et al. Recovery of body composition improves longterm outcomes after lung volume reduction surgery for emphysema. Eur Respir J 2010;36:408-16

9 Koves TR, Sparks LM, Kovalik JP, et al. PPAR $\gamma$ coactivator- $1 \alpha$ contributes to exerciseinduced regulation of intramuscular lipid droplet programming in mice and humans. $J$ Lipid Res 2013;54:522-34.

10 Mineo D, Ambrogi V, Frasca L, et al. Effects of lung volume reduction surgery for emphysema on glycolipidic hormones. Chest 2008;134:30-7. 